\title{
The Application Of The Method Of Metamorphosis In The Folklore Of The Peoples Of The East
}

\author{
Shoira Rustamovna Usmanova \\ Department of Translation, Studies and International Journalism, Tashkent State University of Oriental \\ Studies, Tashkent, Uzbekistan. ushoira@mail.ru
}

\section{ABSTRACT}

In recent years, interdisciplinary research, including folklore, ethnography, linguoculturology and other disciplines, has been expanding. The complex study of materials related to various sciences ensures the complementarity of the fields of science, contributes to a deeper and more systematic understanding of the phenomena of language and culture. In particular, the comparative study of the specific motives and methods in the discourse of mythological traditions and fairy tales in folklore texts serves to determine the way of thinking, mentality and imagination of different peoples.

This article is devoted to the study of the phenomenon of metamorphosis, which is reflected in the folklore of the peoples of the East. Metamorphosis is the transformation of any being or thing, form or species into a new, different form and type, as well as an unusual change in something. Metamorphoses rely on the most ancient mythopoetic ideas and reflect their unique characteristics.

The article comparatively studies the application of the method of metamorphosis in the myths, legends, epics and fairy tales of the peoples of the East, the universal and different aspectsof metamorphoses. The types of metamorphoses, their ways of occurrence, causes, factors and peculiarities are also described.

Keywords; metamorphosis, myth, legend, folktale, epic, fairy tale, hero

Article Received: 10 August 2020, Revised: 25 October 2020, Accepted: 18 November 2020

\section{Introduction}

One of the most common stylistic methods in the examples of oral creativity of the peoples of the East is metamorphosis. Metamorphosis is one of the most ancient and influential methods used in myths and legends, folklore, philosophical and artistic works, such as hyperbole, metaphor, simile.

The Encyclopedia of Mythology defines the concept of "metamorphosis" as follows: Metamorphosis (Greek. Metamorphosis): 1) the transformation of one being or thing into another; 2 ) the transformation of any form or species into a new, different form and type; 3) an unusual change in something.

The modern literature on stylistics contains conflicting views on the nature of metamorphosis and the functions it performs. According to the Russian linguist D.E. Rosenthal, metamorphosis is a very colorful and moving metaphor. It falls into the category of analogies and reflects the process of transition from one event to another, while metaphor and simulation reflect the result [1].

N.D. Arutyunova, on the other hand, argues for a clear distinction between metamorphosis and metaphor. Metamorphosis does not equate the role of the subject, it only preserves its "change". It represents only a "changed" world. This episode, event, appearance goes into the development of the whole plot [2].

According to a number of American cognitive linguists (M. Black, A. Richards, D. Davidson), the essence of any stylistic method lies in conflict [3]. Metamorphosis (along with metaphor) serves to confirm this completely. Being transformed into another image and projecting from one system to another is the basis of the conflict. Based on this thesis, metamorphosis can be interpreted as a new view of the object, which 
means the concept of transformation into another type [4].

According to E.M. Meletinsky, metamorphoses reflect the peculiarities of early mythopoetic ideas in archaic forms: due to metamorphoses, gods are imagined with people, animals with inanimate objects, and sometimes they turn into each other. The clear boundary between the "world of the living" and "the world of the dead", "that world" and "this world", the transition from one dimension to another is manifested through metamorphoses [5].

The phenomenon of metamorphosis has been studied as a topical issue in the works of ancient Chinese philosophers as well: The idea of metamorphosis was first mentioned in the Book of Changes, in which the Thai hexagram and the Pi hexagram combine the variations of opposites. For example, this is observed in such lines as "When the little one leaves, the big one comes", "When the small one leaves, the big one comes", "There is no slope without the plain", "There is no return without the departure", "Happiness comes after the tragedy" [6].

The analogy of these linguistic metamorphoses can be seen in the following Uzbek articles: "If you sit narrow in a wide place, you sit wide in a narrow place", "He who laughs a lot cries a lot", "If the moon is dark, and it is fifteen lights".

The phenomenon of metamorphosis is evident in folklore. Metamorphoses, in particular, are an element that serves as a key ring in the emergence of the plot of legends, myths, fairy tales and epics.

Because totemism was so prevalent in primitive culture, animals, birds, fish, insects, and even rocks, trees, and grasses were thought to have human-like souls and spirits, "all creatures in nature are spirits of the dead". This led to the formation of specific metamorphoses.

\section{The Main Findlings and Results}

The following manifestations of metamorphoses are observed in the oral art of the peoples of the East:

\section{The metamorphosis of "man $\rightarrow$ animal"}

In folklore, the motive of a person becoming an animal by changing his appearance for various reasons is called "becoming an animal or entering the image of an animal" [7]. In folklore, access to the image of an animal, while not an easy task, seems to be the norm. Appearance changes are very quick and easy. A bird, a horse, or a snake can appear as a result of movements such as fluttering its wings, squeaking, or fullness of body [8].

In the folklore of the peoples of the East, the transformation of the human image into animals such as foxes, snakes, frogs, dogs, wolves, and monkeys is common:

Turning into a fox. In Chinese folklore, the image of a fox, which can take on a different color with a spell, is especially prevalent. The image of the fox (ku-li) in Chinese mythology is one of the most controversial and complex characters. According to ancient Chinese beliefs, a fox becomes a woman at the age of fifty and a young girl at the age of one hundred. A fox that has lived for a thousand years will have nine tails, and it will become the Celestial Fox (ten-hu). The Celestial Fox can enter not only the female image, but also the male image. Therefore, the phrase "狐 仙" or "狐狸" (a fox can take on a different color with a spell) is common among the people [10].

In the works of medieval Chinese novelist $\mathrm{Pu}$ Sungling, it is very common for women to become foxes and vice versa, when a fox becomes a woman or a man in general. For example, in his novel The Master of the Military, he describes how he became a fox: "Wang and his wife took the opportunity to spend time together. Sometime later, the woman became drunk and fell asleep on the table. Then the woman turned from a human to a fox. Seeing this, the girl felt sorry for the fox and put a blanket over him. At that moment, the master returned home and, seeing the situation, tried to kill the fox. The girl protested, "What has he done to you, even though he is a fox?" But the master did not listen to him and went in search of a knife. At the same time, the fox became a woman again ...".

In the novel YaTou, the female corpse is turned into a fox: "This year, Wang $\mathrm{Zi}$ turned 18 years old. Wang Wen told him what had happened, and showed him his mother's letter. Outraged by this, Wang $\mathrm{Zi}$ set out to rescue his mother and settle accounts with the old woman as well. When he reached his destination, he ran into the house. Nizi 
was drinking wine with a man. Wang Zini turned pale with fear. Wang Zi took his sword and killed him, and Nizi's body immediately turned into a fox". Some time later, the woman became drunk and fell asleep on the table. Then the woman turned from a human to a fox. Seeing this, the girl felt sorry for the fox and put a blanket over him. At that moment, the master returned home and, seeing the situation, tried to kill the fox. The girl protested, "What has he done to you, even though he is a fox? "But the master did not listen to him and went in search of a knife. At the same time, the fox became a woman again ...".

In some Chinese sources, the Fox is interpreted as a negative image, in some sources it is represented as a positive image. In particular, in the work "Feng Shen Yi" in the time of the Ming Dynasty, the Fox penetrated into the body of Suhu's daughter Danji, deceiving Emperor Zhou Wang, doing many evil deeds and flying at the crow of the people. But when describing the magicians in the novelties of the collection of "Fox spells" of the Pu Sungling in the era of the Ching Dynasty, the writer seems to be benevolent to them. The image of a fox-girl can be an example of this. However, in this place we see not a woman who became a Fox, but a Fox who became a woman [11]. He is portrayed as an intelligent, beloved, naive image:

"About a year later, Chui Bing caught sight of two foxes chasing a large dog on the road. One of them ran towards the ruins, and the other hurried out of fear, jumped into Chui Bing's lap, dropped his ear, and slammed into his lap. Chui Bing felt very sorry for the fox. Chui Bing immediately hugged him, put him in his coat, and took him home. When he got home, he quickly put the fox to bed. After a while, he looked at the bed again, where Ching Feng appeared. Chui Bing couldn't believe his eyes. He was overjoyed and asked her about what had just happened. Ching Feng said, "I was walking with a maid when a big dog suddenly appeared on the road. If it weren't for you, the dog would have surprised me. I'm not a human, I'm a fox, and you don't need me. Now you can hate me".

Or, "Wang was very surprised by what happened, and Ya Toy, who felt it, said, "I can tell you the truth, just don't worry. I am a descendant of a magic fox, not a human. Even though that old woman was my mother, she beat me up so often; I have hated her so much ever since. Now we are free from these endless calamities. My mother can't feel things a hundred miles away. So be glad we got here safe and sound". When Wang heard that he was a fox, he was neither afraid nor disgusted, but only sadly said, "Even though I have a beautiful wife like you, but I am very poor, I am afraid you will leave me later".

Becoming a snake. The Chinese folk legend of the White Snake depicts a beautiful goddess who can take on the appearance of a snake who lived in Shaoxing during the Sun Dynasty. One day, he meets a handsome teenager named Syusyan at Lake Sixu. They fall in love at first sight and get married. After the wedding, they go through a lot of hardships. The legend ends with a monk named Fahay imprisoning a beautiful girl in the Leifen Tower.

A similar plot can be seen in the Uzbek folk tale "Snake Fairy":

" - Sir, don't let the girl you brought from this steppe be a Snake Fairy." In the past, old people said: - There will be a snake in the steppe. If a person does not see for forty years, he will become a fairy, and he will look like a fairy during the day and a snake at night. In the middle of the night, when the king woke up, he saw a large, long snake lying next to him. If the head is in the pool, the tail sucks next to the king. The king lay in silence, saying nothing for fear. In the morning, when the king looked, he saw a fairy lying next to him. He did not tell this secret to anyone" (https://ziyouz.uz/ozbek-xalq-ogzakiijodi/ozbek-xalq-ertaklar).

In the Turkish folk tale "Devzikhan's daughter", the girl is simultaneously turned into a frog: the king's son goes to the underwater country and kidnaps Devzikhan's daughter. Dissatisfied with this, Devzikhan and his sons follow them. Seeing this, Devzikhan's daughter turns first into a frog and then into a snake. After the tragedy is over, the girl takes on a human form again. In becoming the animal that is the main character of this tale, it is observed that the protagonist uses a method of protection from the threat that haunts him. This was done at the will 
of the protagonist, whose main goal was happiness and goodness [13].

Turning into a dog. The plot of the myth of the dog-bird was well known to many Turkic peoples, including the Khakass, the Kyrgyz, the Bashkirs, and the Ayrats. In Khakass folklore, there is a legendary dog named "Xubaykhus" from a bird's egg called aat. According to myth, no creature can escape the persecution of this dog. M.I. Borgoyakov noted that the image of a dog-bird was widespread in the mythology of the ancient peoples of Eurasia could not be saved" [14].

Among the Khorezmians there are legends about a dog that flies like a bird. According to the legend of AbduazizQori, a janitor at the tomb of Sheikh NajmiddinKubro, who told ethnographer G.P. Snesarev [15], "There was nothing before the burial place of NajmiddinKubro.

The place is calledKopurjoy, and an old woman who looks after it has planted various fruit trees and turned it into a large garden. The old woman had a son. NajmiddinKubro's eyelashes were so long that they fell over his eyes. If the sheikh wanted to look at this or that person, he would raise his eyelashes with his hand and the person who looked at him would become rich. One day the old woman took her son to the sheikh and said, "Look at my son!" he asked. As the sheikh raised his eyelashes, the old woman's son ran away from his seat and was replaced by a dog, and the sheikh's blessed gaze fell on the dog. So this dog became a divine creature that could fly freely in the air. When the dog died, he was shrouded and buried near the sheikh's grave" [16].

From Uzbek folk tales in "Black hairy angel" there is a story about the transformation of characters into dogs and cats: "The magician was proud", I turned a few people into lifelong dogs and cats with my magic, and I set fire to a few villages and threw the ashes into the sky. I broke up some inseparable friends and made them enemies" he said of his actions" (https://ziyouz.uz/ozbek-xalq-ogzaki-ijodi/ozbekxalq-ertaklar).

Turning into a wolf. Most Turkic-speaking peoples have developed certain aspects of the plot of the ancient Turkic myths about the ancestor of the wolf on the artistic basis of their national folk traditions. As a result, ethnogenetic legends about the origin of this or that Turkic people (for example, the legends about the birth of 92 Uzbek tribes and the origin of the Bashkirs), genealogical legends about the origin of seeds of a particular people (Kyrgyz breeds such as sayak, wolf; Chuvash and Bashkir tribes; Uyshun, legends about the Uzbek tribe called the wolf) and zoomorphic legends about the origin of the wolf (the legend of the Uzbeks of the repressive tribe about the man who turned into a wolf) emerged [17].

In the Turkish folk tale "The Bride Who Was a Wolf", a woman who gave birth to a son is told that a wolf will kill her on the day her son grows up and gets married. When the son reaches the age of marriage, his mother will not allow him to marry. Despite the woman's obstacles, one day her son gets married. On the wedding day, the woman tells the story to the villagers. After the wedding is over, the whole village guards the house. In the morning, when the woman enters the house thinking that her son is saved, she sees that her daughter-in-law has killed her son as a wolf. It can be seen from this tale that the protagonist did not change his image at will. In this case, the dominant power used the man who turned into an animal as a vehicle for human death and disaster [18].

Turning into a monkey. In the Uzbek folk tale "Five Girls" there are motives to turn a man into an ape with a prayer and, conversely, to turn a monkey into a man:

"I didn't know what to do with the girl", I said. He took his sword from me and gave it to Kumush. Kill the guy! He said. The girl said, "Why am I running in vain, if it is not my fault?" In a fit of rage, Giant snatched the sword from the girl's hand and smashed it to pieces. He smashed to the girl and said, "Now how can I kill you?". I said, "It's up to you". Once upon a time I was blown away by reading something and I became a monkey at that time. Giant lifted me up into the sky and flew and dropped me into a scary desert. I jumped from tree to tree like a monkey and walked there for five or six days. I have a mind like a monkey, but I don't have a tongue" (https://ziyouz.uz/ozbek-xalq-ogzaki-ijodi/ozbekxalq-ertaklar). 
In the above tale, the giant turns the protagonist into a monkey with a prayer to punish him, which is then restored to its original state with the prayer of the princess. Here you can see that the protagonist of the work was punished. "This type of punishment is reported in Surat al-Baqara (65) and Nisa (154). People who violate the no-fishing requirement on Saturday will be turned into monkeys"[19]

\section{The metamorphosis of "man $\rightarrow$ bird"}

Turning into a pigeon. The animistic idea of the appearance of a person's soul in the form of a bird (often "dove") is one of the most widely spread acutely motivations in Uzbek folk tales. In particular, in one variant of the mythological legend associated with the cult of Water recorded in the Khorezm Oasis, written by the ethnographer scientist G.P. Snesarev, this ancient element of image was preserved [20] "according to the story, Sheikh Hakimota married the beautiful daughter of Burhan Anbar and gave birth to three sons. His younger brother's name will be Hubby. The father loves his older children, and Hubby is Ambar's mother's favorite. One day Hakimota wants to try his sons. Then Hubby, hearing his mother's call, arrives much later to his parents. When his mother asks him why he is late, he says that the first time he called, he rescued a shipwreck, and the second time, those who had survived the flood resurrected a bull that had been sacrificed for him. Hubby is unable to go out with her father because she did not arrive on time. The government is demanding that he leave the house. Ambar then locks mother Hubby in the house. But Hubby takes off his clothes, turns into a dove, and flies out of a hole in the roof" [21].

According to M. Juraev, the transformation of Hubby into a pigeon in the Khorezmian legends is due to the ancient animistic beliefs of our ancestors that after death a person's soul turns into a bird. Grandmothers in the village of Jigachi in Bukhara's Karakul district say that when they hear that someone's child has died, "someone's child has flown". This phrase also reflects ancient notions that our ancestors saw death not as the end of human life, but as a means of transition from one form of life to another. According to their understanding, the soul is alive, and when a person dies, he turns into something (often) a bird.
That is why the phrase "the flight of a child" used in the Karakul dialect implies the transition of the soul to the sky, that is, to the world of spirits.

Contrary to such notions about John, Hubby turns into a dove and flies away while alive. Hubby's transformation into a pigeon is also motivated by traditional epic interpretations of Uzbek folklore". According to the epic "Princess Artful", Gorogly enters a strange fortress on Lake Shopar in the Zebit desert. As Gorogly watched the wonders inside the citadel, "a blue dove came down from the sky, and a squirrel, a squirrel, a squirrel, a squirrel, a squirrel, a squirrel, a squirrel, a squirrel." After informing Gorogly of his whereabouts and lineage, he jumped up again, put on a dove's robe, and flew into the sky. The image of fairies and giants flying in the form of pigeons is also recorded in Uzbek folk tales. There is also a saying among our people: "Do not harm the pigeons, they will be fairies", "fairies are doves and go around" [22].

Turning into a parrot. The motive of the human soul turning into various birds, especially parrots, can also be found in Chinese folklore:

到了家里, 他又病了, 不吃不喝, 睡梦中还 常喊阿宝的名字。恨不得自己的魂能再到阿宝 家去。一天孙子楚家的一只鹦武, 忽然死了, 小孩们拿着玩儿, 孙子楚看见, 心里想: 要能 变成一只鹦鹉, 不一下子就飞到阿宝身边了吗? 想着想着, 他竟真的变成鹦鹉, 不一会儿, 就 飞到阿宝屋里-When he returned to his house, he fell ill again and lay down without enamel. And in a dream, he always says the name of A Bao. He dreamed that his soul would go to Bao's house again. One day the parrot in the House of Sun Zichu died from the fullness. The children were playing the dead of the bird. Sun Zichu saw this inside: - " if I had become a bird, I would have flown immediately next to A Bao." At that moment, though he suddenly got turned into a parrot, flew into A Bao's House and landed [23].

In the Uzbek language, the following euphemistic metamorphoses associated with the transformation of the soul into a parrot can be seen: euphemistic metamorphoses such as spirit parrot ... fly, spirit parrot ... accepted, spirit bird ... fly can be encountered. The narrator says that even though he recited forty thousand verses 
for forty days, ... the parrot of the spirit flew to the candy of paradise; ... after a while the spirit parrot flew from the cage of the body to the gardens of flight; The spirit bird flew from the cage of the body to the branch of the tree of paradise.

In addition to the above, in Chinese linguoculture there are 华鹤 huáhè -“turning into a crane, going into the world”, 跨鹤 kuà hè "climbing on a crane (eternal life)", 跨鹤 kuà hè "ride a crane" and so on., euphemistic metamorphoses are also used.

Turning into a bird. One of the most common motifs in Turkish folk tales is that girls look like birds. For example, in the fairy tale "The Sewing Girl", a girl who turned into a bird as a result of magic performed by stabbing needles, returns to her old state when her husband takes out the needles. In the fairy tale "Coral Girl" there is a story about a girl who turns into a bird when she pulls out three white pins in her hair. In the story "The Golden Boy and the Golden Girl", the three fairy-tale birds become three girls on the fourteenth day of the month.

The Uzbek folk tale "Five Girls" depicts a girl transforming herself into three creatures - a dove, a dog and a lion: "After a while we were sitting in the king's garden, and a dove appeared in the sky. The girl stood up: "The magic giant came to fight me," he said. He himself was a big black bird reciting a prayer, caught with a dove. At one point, the pigeon fell to the ground and became a round dog. The girl turned into a lion - they got it again" (https://ziyouz.uz/ozbek-xalq-ogzaki-ijodi/ozbekxalq-ertaklar).

In the plot of fairy tales, metamorphoses often occur by penetrating the skin of any animal or covering it with the feathers of birds. For example, in the fairy tale "White Bird-Girl" written by writers of the Jin dynasty (Go Pu, GanBao), 7 beautiful girls with bird feather veils is depicted. When the protagonist pulls the veil that one of them has thrown over his shoulder, this beautiful girl is left unattended and marries him. When they have 3 daughters, the white bird-girl flies to her homeland wearing a feathered veil she has hidden. $\mathrm{He}$ will return later and take his daughters with him. Apparently, "the changed appearance, the changed form is a means of transfer to another world".

The same plot with the tale of the "Swan-Girl" can be seen in Korean folklore and Altai folk tales: "A young man comes to the lake and sees girls bathing naked, leaving their clothes on the shore. He steals the clothes of one of the girls as a game. The girls all turn into white birds and geese and fly away. But the girl whose clothes were stolen stays on shore. She married that young man and had a son. But then he finds a bird's coat (feather cover) and flies home. The above-mentioned plot can also be found in the epic Manas. In the epic Manas, Oychurak threatens to go to his father Aqinkhan, dressed in the white bird costumes of Erkiyaz, who is trying to kill his son. At this point you can see him wearing a feather blanket whenever he wants and turning into a white bird.

The image of an animal penetrating its skin or covering itself with bird feathers can be seen in most Uzbek fairy tales. For example, in the fairy tale "Oppression", the girl runs away from her father's marriage and hides in a felt. In another tale, a hunter-gatherer takes the hero in a tulpa across the river and takes him to the place of the dead.

In the story of the Five Girls, the potters condition the hero to reveal the secret of why they are crying: "Go to the market and bring a big sheep, slaughter it and give it to us. If you put it in your skin, then we will tell you these secrets." The protagonist fulfills the condition, but while lying on the skin, the semurgcomes and picks it up and tries to take it to the desert to eat. As soon as it comes out of the skin, the semolina flies away in fear. The protagonist is left in the desert for the second time. The conclusion is that in order to know something, the appearance is changed, and the appearance of the semurg takes the changed hero to another world - the desert" [25].

\section{C. "Man $\rightarrow$ insect" metamorphosis}

It is one of the most common phenomena in myths that a person turns his soul into a butterfly after death. For example, in the Chinese legend of LianShanbo and Zhu Intai, during the Eastern Jin dynasty, Intai, the daughter of a rich man named Zhu Jiachjen, met a teenager named LianShanbo on the way to school. The young men fall in love 
with each other, but the girl's family resists their marriage. As a result, youngsters perish and become inseparable butterflies.

In addition, 羽 化 yǔhuà -euphemistic metamorphoses such as "like a butterfly out of a cocoon" and 升天 shēngtiān - "ascending to heaven, entering paradise" can be found in Chinese lingoculture.

\section{Metamorphosis of "Man $\rightarrow$ extraordinary being"}

According to the beliefs of the ancient Chinese, if the source of eternal life is found, the creature can take on the form of a human being or, conversely, take on the form of a human being and develop a magical nature and live forever:

只见一个牙齿又尖又长的恶鬼, 正把一张人 皮铺在床上，拿着画笔在上面描画。花了一阵， 把画笔扔在一边, 拿起画好的人皮, 好像穿衣 服一样披在身上, 马上就变成了那美丽的少女。 -Then he saw a creature with sharp and long teeth. In bed, a man's skin was spread out. As the creature held the brush, he drew on it with his whole body. When he had finished drawing, he threw the brush to one side. The beautifully drawn man took his skin in his hands and put it on as if he were wearing a robe. At once, the creature became that young girl again.

In examples of folklore, giants are embodied as supernatural abilities, the possessors of enormous magic. They have the ability to turn people into apples, rings, etc., restore them to their original state at any time, or even change their appearance. In fairy tales and epics, giants sometimes come in the form of a horse or turn into a round horse. When the giant sponsors the hero, he moves him from one place to another, from one world to another. These notions are primarily related to the cult of the horse, which, according to the beliefs of our ancestors, descended from the sky. According to one legend, horses were descended from gods and dragons. For this reason, winged horses are common in folklore. Winged, giant, humanly intelligent and loyal horses are depicted in folklore as the hero's friend, companion, various disasters, underground sounds, earthquakes, beasts that foretell magic. With these characteristics, horses are compared to giants. Giants are also sometimes given using the tiger symbol. While this symbol refers to its savagery on the one hand, on the other hand, the tiger is interpreted in Turkish mythology as the spirit of a mountain and a cave. According to popular belief, giants came out of caves sometimes as horses, sometimes as tigers, sometimes as dragons, sometimes as wind. It is an expression of the shamanic view that the soul passes from one form to another, according to which the evil spirit can come out of its place in various forms [26].

In the oral tradition of the peoples of the East, the dragon is one of the most complex and universal symbols representing the legendary giant snake. In the ancient beliefs of the Turkic peoples, the dragon was a symbol of blessing, prosperity, abundance, and strength, but in later times such qualities were weakened and it appeared as a symbol of evil. In Uzbek folk tales, the dragon is a symbol of an evil, wild spirit. In the legends and myths of the Indian, Greek, and Armenian peoples, the dragon is depicted as the god of water, fertility, floods, rivers, seas, and other elements of nature.

Although the dragon is an imaginary, mythological animal, it plays an important role in Far Eastern culture. In China, it is believed that the dragon appeared 8,000 years ago. In ancient times, the Huasia tribe totemized a snake that lived on the banks of the Huanghe River. He defeated the other tribes, united them, and formed a strong tribe. As a result, the snake totem and the totem of other tribes merged to form the "dragon" totem.

The Chinese consider themselves the descendants of the dragons. During the Shang dynasty, the dragon was seen as a symbol of goodness, power, and happiness. Later, the dragon became a symbol of the emperor's "power." The dragon and the ruler are united, and the ascension of the ruler from the earth to heaven, the son of Heaven, who is above the believers, is likened to a dragon. People's belief in the power of the dragon came in handy to the rulers of China and Korea, and they took advantage of this superstition. About the emperor: his face is the dragon's face, his eye is the dragon's eye, his hand is the dragon's hand, his coat is the dragon's coat, his children are the dragon's children, the emperor's palace is the dragon's palace, his throne is the dragon's place, 
and so on., beliefs were widespread among the people [27].

In the folklore of the peoples of the East one can also find the motive of entering the image of man as a dragon. In particular, Zol enters the image of a dragon to test his sons. There is also a custom in the shamanism of the peoples of the East to take the form of a dragon (mask) and perform various rituals.

\section{E. "Man $\rightarrow$ body, element" metamorphosis}

In the oral traditions of the peoples of the East, it is not only the appearance of man in the form of an animal, bird, or insect, or vice versa, but also his transformation into various bodies and substances, such as stone, water, salt, and so on.

Turning to stone. Stone hardening, turning to stone, is a very common motif in examples of folk oral art. Legends have different reasons for turning to stone. Sometimes turning into a stone causes a curse, sometimes sinners become a stone in the wrath of God. It is also possible to turn to stone at will. Those who are in a very difficult and helpless situation ask God to turn them to stone in order to get rid of such a situation. [28] For example, in the Uzbek epic "Princess Artful" the following curse can be observed which encourages people to turn to stone: "Let the ball go. Let not the footsteps of the scoundrels, let anyone who says a word be a stone".

In fairy tales, however, turning to stone is done through magic, sorcery and magical powers. In fairy tales, there is no basis, no sign of turning to stone [29]. In the Turkish folk tale "Three Poor Girls", a golden-haired young man who set out to get a girl with claws at the urging of his sister sees hundreds of people surrounded by stones when he goes to the place where the girl lives. Three times he calls the girl with clawed teeth "bismillo" and the stone freezes there before his voice reaches the girl. When the girl goes to him and prays, the golden-haired young man becomes human again. The rest of the people who turned to stone there also became human beings and set out as soldiers [30].

The frozen young man and the motive for his return to the original can be seen in Uzbek folk tales in "Black hairy Angel": Fourth: "His father built a new building and left the scorpion, so that my son could come, bite, die, and his wife should stay with me". I've been lurking at the scorpion all night, and today the Black Fairy was asleep, crawling over her hair, and I pushed it aside with my sword, and it split in two and a drop of poison splashed on my sister's face; I was wiping the poison with a handkerchief to keep the poison from spreading, and you came, "he pointed to the scorpion, which was splitting in two. If you don't believe, your whole body will turn to stone" (https://ziyouz.uz/ozbek-xalq-ogzaki-ijodi/ozbekxalq-ertaklar).

Even in Chinese folk tales, the phenomenon of petrification is a common metamorphosis. For example, in the fairy tale "Magic Picture", the prince sees a picture of a beautiful girl and falls in love with her, and he finds her and brings her. Upon learning of the incident, the servant turns to stone for warning his master of danger. The prince rescues and resurrects his servant through the blood of his children. In the end, their children also miraculously come back to life.

Turning into water. The motives of the protagonists of the work to become water are also common in the examples of folklore. For example, according to ancient beliefs, the world was originally water, and water was considered the boundary between the worlds. The Genesis chapter of the Torah describes the creation of the world as follows: "From the beginning God created the heavens and the earth. The earth was still formless and empty, and darkness reigned over the abyss. The spirit of God was flying on the water" [31]. Most people's view water as a place where spirits live.

In the Uzbek epic "Princess Artful ", Boymoq wants to turn into water to kill the princess: “... When the princess takes her angel and comes back to Koklam Mountain, she will fight for a long time, she will suffer from thirst, her tongue will sting, and she will regret that she drank water. Then I lie down as test water. He will drink me as water, and I will be poisoned and killed".

In the Turkish folk tale "Devzikhan's daughter", the king's son, who fell in love with Devzikhan's daughter, goes to the country where the girl lives. Devzikhan's daughter escapes with the king's son without the consent of his mother. As Devzikhan and his sons follow them, Devzikhan's daughter 
turns the king's son into water, and she herself turns into a frog and swims in the water.

Turning into Salt. In the Genesis chapter of the Torah Bible, it is said that despite the warnings that lot of the Angels who came to destroy the cities of Sadom and Gomorrah," run away without looking back, "his wife looks back and becomes a pillar of salt.

Turning into things. This is where the "object $\rightarrow$ object" metamorphosis often occurs. For example, in the Uzbek folk tale "The rich and Angel" the transformation of a pair of scissors into a thicket is described as follows: After two nights and two days, the lizard reached them. They dropped the scissors and fled. Scissors have also become a big thicket with no visible beginning and end (https://ziyouz.uz/ozbek-xalqogzaki-ijodi/ozbek-xalq-ertaklar).

In the fairy tale "Ernazar and Kimyonazar" the stable is turned into a house and vice versa: the house is turned into a stable: "When Ernazar was at night, he called Kimyonazar and gave the stables a much better home trip; he himself became a prince and could do the party before dawn. At dawn, the house was again turned into a stables" (https://ziyouz.uz/ozbek-xalq-ogzakiijodi/ozbek-xalq-ertaklar).

\section{Conclusion}

Folklore is an important part of the culture and history of a particular nation. Folklore works are passed down from generation to generation, polished, enriched and attractive. Examples of folk oral art reflect the worldview, mentality, development of society of the nation and, unlike other genres of art, embody the style of deep philosophical observation of the people.

Metamorphosis is the transformation of any being or thing, form or species into a new, different form and type, as well as an unusual change in something. Metamorphoses rely on the most ancient mythopoetic ideas and reflect their unique characteristics.

The roots of the oral creation of the peoples of the East are connected with the notions of divine power. Because totemism was so prevalent in primitive culture, animals, birds, fish, insects, and even rocks, trees, and grasses were thought to have human-like souls. As a result of such perceptions, a metamorphosis of negative and positive characters was formed in folklore works. Also, any taboo or violation of the prohibition in the samples of folklore has caused metamorphoses.

The oral traditions of the peoples of the East are characterized by the prevalence of metamorphoses in the structure of "man $\rightarrow$ animal", "man $\rightarrow$ bird", "man $\rightarrow$ insect", "man $\rightarrow$ supernatural being" and "man $\rightarrow$ body, element". There are cases when the opposite of these structures. In the folklore of the peoples of the East, metamorphoses in the form of "man $\rightarrow$ animal" and "animal $\rightarrow$ man" are distinguished by their productive use. Consequently, in the collection "Guan and tzi" ("Unusual Records"), compiled by Day Fu during the Tang Dynasty in China alone, one can see metamorphoses in the form of 33 magical fox-girls, 16 magical tigerboys and 11 magical snake-girls.

The unique fauna and flora of each Eastern country was also one of the important factors in the emergence of metamorphoses in the oral art of the peoples of the East. Therefore, in the folklore of the Chinese and Korean peoples, the motifs of foxes, snakes, white birds, parrots, butterflies and dragons, and in the folklore of the Uzbek and Turkish peoples, the motifs of dogs, wolves, horses, monkeys, snakes, frogs, pigeons, white birds and monsters are common. At the same time, it should be noted that the motif of stone solidification is characteristic of the oral art of all the peoples of the East.

\section{References}

[1] D. E. Rosenthal Handbook of stylistics of the Russian language. Moscow: Iris Press, 2013, p. 329.

[2] N. D. Arutyunova. Metaphora [Metaphor]. Linguistic encyclopedic dictionary.Moscow, 1990, p. 296-298 (in Russian).

[3] M.Black More about metaphor. Metaphor and thought.Cambridge, 1979, pp. 19-45.

[4] M.Black Models and metaphors: Studies in language and philosophy.Ithaca, 1962, p. 128.

[5]. E. M. Meletinskij Poetica mifa [Poetics of the myth].Moscow, School "Languages of Russian culture” Publ., 1995, p. 225. (in Russian). 
[6]. U Chun. Philosophical ideas. Tashkent: Academic Print, 2019, p 80.

[7] Ergun Metin. Change Motif in Turkish World Legends. Ankara: Turkish Language Association Publications, 1997, p 177.

[8] Roux Jean Paul. Sacred Plants and Animals in Central Asia. (Translated by: AykutKazancigil - LaleArslan). Istanbul: Kabalc1 Publications, 2005, p. 234.

[9] Sh. UsmanovaLinguocultural aspects of translation. Tashkent: TSUOS, 2017, p. 161.

[10] KebaytuliGulibanumu. Interpretation of animal symbols in Chinese and Uzbek linguocultures // Sharq torch. No. 3-4. Tashkent: 2015, p. 59.

[11] J. Ziyamuhamedov Medieval Chinese short stories. Tashkent: TSUOS, 2010, pp. 90-91.

[12] Ke. Yuan Myths of ancient China. Moscow: Science, 1965.

[13] ÖzcanDerya, Kaval Yilmaz. The Transformation Motifs in the Fairy Tales Collected from Tunceli // Journal of Motif Academy of Folklore, 2019. Vol. 12, No. 26, pp. 320-321.

[14] M. I. Borgoyakov About one ancient mythological plot, its evolution and reflection in the folklore of the peoples of Eurasia // ScythoSiberian cultural and historical unity. Materials of the I All-Union Archaeological Conference. Kemerovo, 1990, p. 276.

[15] M. Juraev Fundamentals of folklore. Toshkent: 2008, p. 19.

[16] G. P. SnesarevKharazm legends, as a source on the history of religious cults of Central Asia. Moscow: Nauka, 1983, p.153.

[17] M. Juraev Fundamentals of folklore. Toshkent: 2008, p. 14.

[18] Özcan Derya, Kaval Yilmaz. The Transformation Motifs in the Fairy Tales Collected from Tunceli// Motif AkademiHalkbilimiDergisi, 2019. Vol. 12, No. 26, p. 321.

[19] Sh. Nazarova Imagination and reality are at the crossroads of folklore and theology. Tashkent: "Classic word", 2013, p. 44.
[20] M. Juraev Fundamentals of folklore. Tashkent: 2008, p. 46.

[21] G. P. SnesarevKhorezm legends as a source on the history of religious cults of Central Asia. Moscow: Science, 1983, p. 251.

[22] M. Juraev Fundamentals of folklore. Tashkent: 2008, pp. 46-47.

[23] J. Ziyamukhamedov Medieval Chinese short stories. Tashkent: TSUOS, 2010, pp. 189190.

[24] H. L. Sarıyüce Anatolian Tales. Istanbul: Kap1 Publications, 2010, pp. 111-361.

[25] Sh. Nazarova Imagination and reality are at the crossroads of folklore and theology. Tashkent: "Classic word", 2013, pp. 45.

[26] J. Eshonkulov Folklore: image and interpretation. Against: 1999, pp. 27-69.

[27] E. N. Filimonova The symbolism of animals in translated works. "Sacred" animals (based on translations from Korean and Chinese) // Language, consciousness, communication. Moscow: MAKS Press, 2004. Issue. 26, p. 53.

[28] FeyzioğluNesrin. An Evaluation on Stone Cut Motif in Gelin Kaya Legends // Gazi Turk studies. No. 9, pp. 115-133.

[29] Ergun Metin. Change Motif in Turkish World Legends. Ankara: Turkish Language Association Publications, 1997, p. 47.

[30] ÖzcanDerya, Kaval Yilmaz. The Transformation Motifs in the Fairy Tales Collected from Tunceli// Motif AkademiHalkbilimiDergisi, 2019. Vol. 12, No. 26, p. 319.

[31] The Bible. Turkish Bible Society. 1995, p. 625.

[32] N.R.IsmatullayevaLacunas in Chinese and Uzbek Languages and Methods of Their Detection. International Journal of Innovative Technology and Exploring Engineering (IJTEE). ISSN: 22783075, Volume-8 Issue-12, October 2019. - pp 2095-2099. DOI: 10.35940/ijitee.L3287.1081219 